\title{
Materialność ruchomego języka
}

\author{
The Materiality of the Language Movement
}

\begin{abstract}
In this paper I reassess Adam Wazyk's meta-poetical statements of the late 1960s and 1970s as also being a time of recovery for crucial avant-garde conceptions in Poland. The artist starting his poetic career as a member of "Nowa Sztuka" ("New Art") avant-garde group around the 1920s, didn't abandon his early intuitions on art after World War II. These in turn can be bound to his life-interests in French avant-garde poetry and in French surrealism. By indicating the poetic affinities of these art strategies, I attempt to highlight similar sources of surrealistic experiments in poetry in France and in pre-war Poland. In this particular case this brings us to avant-garde film techniques, seen through the prism of Deleuze's dissertation on "Cinema", especially in relation to his remarks on the early silent-movies. The notion of 'movement-image', created in the wake of Bergsonian philosophy in relation to time and movement in modernity, occurs as helpful in that matter. The core of my argument connects to the phenomenon of materiality often associated with surrealist practices, invoking here questions of a quite specific kind, that is questions about the matter of language and the matter of poesies.
\end{abstract}


* Instytut Filologii Polskiej Uniwersytetu Wrocławskiego Plac Nankiera 15b, 50-140 Wroclaw

e-mail: joannaorska@gmail.com

Artykul powstał w ramach pracy nad grantem „Nauka chodzenia”. Świadomość późnonowoczesna w metapoetyckich wypowiedziach przedstawicieli polskiej neoawangardy lat 60. i 70. XX wieku (nr rej. $11 \mathrm{H} 130651$ 82; 0064/NPRH3/H11/82/2014). 
W tym szkicu spróbuję się odnieść do surrealistycznych koncepcji wiersza i języka w polskiej liryce awangardowej - przede wszystkim na podstawie powojennych, metapoetyckich wypowiedzi Adama Ważyka jako jedynego właściwie istotnego po wojnie przedstawiciela środowiska „Almanachu Nowej Sztuki” ${ }^{1}$. Dzieje „Almanachu” omówił skrupulatnie w swojej książce Aleksander Wójtowicz, nie chodzi mi więc o ponowne przedstawienie poetyckich idei przedwojennego ugrupowania - choć do programu Stefana Kordiana Gackiego również będę się po trosze odwoływać (Wójtowicz 2017). Chodzi raczej o wskazanie potencjalnej ścieżki transferu „surrealistycznych” koncepcji w lata powojenne. Ze względu na ograniczone rozmiary tego artykułu nie będę mogła odnieść się do dzisiejszych odbłysków przedwojennej, surrealistycznej konstelacji; zaznaczę jednak od razu, że jeśli weźmiemy pod uwagę mocny projekt artystyczny Andrzeja Sosnowskiego, niejednokrotnie na swojej drodze twórczej zwracającego się ku poezji Ważyka ${ }^{2}$ - a także całe grono młodszych (i najmłodszych) poetów, którzy wiele się od Sosnowskiego nauczyli (jak Adam Zdrodowski i Marcin Czerkasow, Agnieszka Mirahina, Bianka Rolando czy Tomasz Pułka i Radosław Jurczak) będziemy mogli powiedzieć, że dochodzi dziś wręcz do swoistej restauracji surrealistycznych

1 Przedwojenną, awangardową karierę Ważyka z jego twórczością po wojnie łączyło już wielu badaczy, w bardzo przekonujący sposób (Krzysztoszek 1985; Kluba 2004). W ramach tego opracowania spróbuję w szerszym kontekście uzasadnić i jednocześnie uzupełnić te uwagi, zwracając się ku zbieżnościom pewnych awangardowych jeszcze przewartościowań i koncepcji z przemianami myślenia o kulturze i sztuce, właściwymi już dla późnej nowoczesności, a wiązanymi ze zwrotem poststrukturalistycznym czy też (z punktu widzenia dyskusji o sztuce) z neoawangardą. Taki punkt widzenia zostaje także przyjęty dla pracy zbiorowej, ukazującej obecność metarefleksji artystycznej dawnych awangardzistów w drugiej połowie XX wieku, zwłaszcza w odniesieniu do światowej rewolucji studenckiej 1968 roku (Nauka chodzenia 2018 i 2019). Koncepcje Gillesa Deleuze'a, do którego ujęcia sztuki odnoszę się w tym szkicu bezpośrednio, nie byłyby możliwe bez zakorzenienia zwrotu poststrukturalistycznego właśnie w ideach wyrastających z przedwojennej, francuskiej awangardy — jej specyficznej, często determinowanej surrealizmem, lektury Marksa, Nietzschego i Bergsona, z której wyrastały przemyślenia George’a Bataille’a, Maurice’a Blanchota, Michela Leiris czy Rogera Caillois. Powracające w wypowiedziach Deleuze'a odniesienia do patronatu Artura Rimbaud, Lautréamonta czy w końcu Antonina Artaud wskazują na awangardowe korzenie wywrotowych projektów Kapitalizmu i schizofrenii, opus magnum tego autora stworzonego wspólnie z Félixem Guattariam. Zdaję sobie sprawę z pewnej zdawkowości zestawienia koncepcji Deleuze’a/Guattariego z programem artystycznym Ważyka; punktem wyjścia dla takich rozważań może być założenie, że dwudziestowieczna awangarda nie utraciła nigdy swego zasadniczo kosmopolitycznego, międzynarodowego charakteru, w perspektywie politycznej powiązanego z ideami socjalizmu. O związkach widzenia Ważykowej poezji z obrazem i filmem pisał także Tadeusz Brzozowski (1994).

2 Por. chociażby posłowie Sosnowskiego (2011) do autorskiego wyboru wierszy Adama Ważyka, stanowiącego swoisty hołd dla tego poety. 
tendencji w języku nowej poezji. Jak się wydaje, w pewnej mierze wypływa to z Ważykowych właśnie inspiracji; jest związane nie tyle i nie tylko ze swoiście baśniową, surrealną poetyką lirycznej codzienności, ale także z hipernowoczesną świadomością twórcy, niosącą w sobie nie tylko spuściznę jego francuskich (kubistycznych i surrealistycznych) tłumaczeń, ale i wyrazisty, w polskiej perspektywie widoczny tak mocno dopiero w latach 90., impuls do rozmywania granic pomiędzy poezją a prozą ${ }^{3}$.

Znamy liczne twierdzenia dotyczące tego, że polski surrealizm się nie udał; ich podstawę mogą stanowić słowa, które wypowiedział sam Ważyk w Dziwnej historii awangardy. Według poety nie mógł on przynieść bardziej wymiernych efektów w krajach, które cieszyły się „intensywną, bujną poezją romantyczną” (Ważyk 1976: 98). Podobne tezy związane być mogły z polskim ujęciem romantyzmu: dość jednostronnym, fantastyczno-wyobraźniowym - więc sprzecznym z oświeceniową (wymienne na zdroworozsądkową) koncepcją rzeczywistości, ale także z wyrozumowanymi formami wiersza ${ }^{4}$. We wstępie do swojej antologii surrealizmu Ważyk pisał więc: „Romantycy francuscy prawie nie znali fantastyki. Surrealiści uprawiali grę wyobraźni, nie oglądając się na żadne normy [...]. Dopiero surrealizm miał wprowadzić romantyczną koncepcję obłędu" (Surrealizm — antologia 1976: 7). Z drugiej strony jednak polski romantyzm miał w interpretacji poety bardziej złożony charakter, przy czym ten ożywiany w neoromantycznym wariancie, w swojej emocjonalno-uduchowionej postaci, zdecydowanie nie znajdował aprobaty autora Labiryntu. Dowiedzieć się można było o tym, czytając chociażby Cudowny kantorek, w którym autor Poematu dla dorostych pisał m.in. o „realizmie”, czy też raczej „materializmie” poezji Mickiewicza5 ${ }^{5}$ Co oznaczał Ważykowy surrealistyczny „materializm”?

Wyobraźnia romantyczna miała według Ważyka charakter „materialny” per se, co oznaczało przede wszystkim, że była powiązana ze swoiście rozumianym konkretem, przejawiającym się jednak w perspektywie sztuki w dość odrealniony sposób. Wyobraźnia surrealistów

3 Oczywiście unieważnianie tej granicy, zasadniczej np. z punktu widzenia tradycji Awangardy Krakowskiej, miało miejsce w rozmaitych eksperymentach poetyckich w powojennej poezji, chociażby w twórczości Białoszewskiego, ale także Różewicza czy w niektórych aspektach u Wata. Sposób, w jaki ci poeci podchodzili do kwestii prozy poetyckiej (czy też poematu prozą), stanowil jednak na tle naszej poetyckiej praktyki wyjątek; ich strategie także różniły się w dużej mierze od postulatów w sprawie wiersza wolnego spod znaku Ważyka. Oczywiście były też próby przekroczenia rygorystycznego rozdzielenia prozy i poezji w ramach awangardowych, wywodzących się z teorii Peipera eksperymentów poetyckich, jak choćby słynne Pióro z ognia Juliana Przybosia. W tym miejscu odwołuję się więc raczej do awangardowych i formalistycznych zarazem przesłanek, które stoją za lekturą wierszy poetów Awangardy Krakowskiej we wczesnych lekturach polskich strukturalistów (przede wszystkim Janusza Sławińskiego i Aleksandry Okopień-Sławińskiej), których rozważania wersologiczne przyczyniły się do głębokiego utrwalenia opozycyjności pojęć poezji i prozy.

4 Wydaje się, że Ważyk pozostaje zakładnikiem polskiego wariantu romantyzmu dychotomicznie rozdzielającego wyobraźnię i formę. Ta dychotomia wcale nie musiała być oczywista; przedstawiciele wczesnego romantyzmu jenajskiego na przykład uważali się w dużej mierze za kontynuatorów późnej myśli Goethego i Schillera, więc klasyki weimarskiej. Trudniej natomiast byłoby ich kojarzyć z tendencjami z okresu „burzy i naporu”, które w większej mierze przyczyniły się do ukształtowania polskiego pojęcia romantyzmu (por. Namowicz 2000). Dla poety ważnym pozostaje jednak mocny związek, jaki zachowywał poetycki kubizm, przede wszystkim Apollinaire'owski, z klasycznymi formami wiersza.

Guślarz zna trzy kategorie duchów, lekkie, średnie i ciężkie. Wszystkie tak samo cielesne jak ludzie, żaden reflektor ich nie wyodrębnia, nie dodaje im nietutejszego blasku. Bo to są duchy wierzeń archaicznych, które nie przeszty przez szkołę neoplatoników. Są tej samej konsystencji, co my, co nasi bliscy umarli, z którymi rozmawiamy we śnie, nie zdając sobie sprawy, że nie żyją. [...] W Panu Tadeuszu ogórek wzmiankowany w opisie sadu staje się namacalny. Tak to odczuwam i wiem, że tak samo odczuwa to wielu ludzi. Przywiązanie do materii nie przychodzi do nas nagle, nie spada z nieba. (Ważyk 1979: 28-29) 
miała być siłą poznawczą - wykształconą przy tym, mówiąc słowami Rimbauda, „poprzez świadome rozprzężenie wszystkich zmysłów” (Rimbaud 1993: 302). Cytat z Listu jasnowi$d z a$, przywoływany w pierwszym Manifeście surrealizmu przez Bretona, pokazuje świetnie, w jaki sposób surrealizm mógł być połączeniem filozofii Marksa i poezji Rimbauda (Janicka 1985: 9). Nie tylko fantastyczny, ale także niepozbawiony impulsu formalnego, a zarazem właśnie „materialny” czy też „przedmiotowy” charakter poezji surrealizmu francuskiego dokumentuje Jakub Kornhauser w książce Catkowita rewolucja. Status przedmiotów w poezji surrealistycznej ${ }^{6}$. Chciałabym pójść tym tropem i wskazać nie tylko na realizację surrealistycznych koncepcji w postaci swoistego „przedmiotu” bez desygnatu — ready-made czy objet-trouvé powstającego na skutek artystycznych zabiegów jukstapozycji i kolażu. Surrealistyczne koncepcje wiersza Ważyka są już bowiem u podstaw, w samym podejściu do poetyckiego języka, materialistyczne - ze względu na przekonanie poety o swoistej „materialności” wiersza: materialna pozostaje więc u niego także wierszowa forma rozumiana jako zapis utrwalający poetyckie doświadczenie.

„Surrealistyczność” zarówno samego „Almanachu Nowej Sztuki”, jak i koncepcji poetyckich Ważyka, rozumiana w kategoriach rzeczywistego związku z francuskim surrealizmem, to oczywiście dyskusyjna sprawa. Jakkolwiek poeta był autorem tłumaczeń francuskiej poezji i tekstów programowych w antologii surrealizmu, z których wiele poznał już przed wojną, trudno byłoby założyć bezpośredni wpływ samych manifestów André Bretona zwłaszcza na dojrzały program estetyczny czy wersyfikacyjne projekty autora Labiryntu. Jednak wiele strategii Ważyka przypomina pomysły surrealistyczne - wywodziły się one przecież z lirycznej rewolucji, której podstawę dał Artur Rimbaud. W rozdziale Dziwnej historii awangardy, zatytułowanym Odwet materii, Ważyk — zastanawiając się właśnie nad obecnością francuskiego „mistyka w stanie dzikim” w świadomości polskiej awangardy — pisał:

Przypomnijmy sobie, że łacińska materia pochodzi od łacińskiej mater. Wbrew domniemaniu romantyków prawdziwe dzieciństwo nie jest po stronie ducha, ale po stronie materii, wierzy się wtedy w fetysze i wszystko jest materialne, postacie bajeczne, aniołowie i Bóg. (Ważyk 1976: 51)

Dalej zaś mówił:

Groteskowy, absurdalny poemat Na temat kwiatów, w którym można dojrzeć zadziwiającą prefigurację futuryzmu, nie był jeszcze odnaleziony. Futuryści warszawscy nie znali nawet „listu jasnowidza”, nikt go u nas nie znał i znacznie później. Ale znaleźli się w podobnej sytuacji powiązania buntu obyczajowego z artystycznym i pierwiastkowego przywiązania do materii. Odrzucając starą poezję jako zbyt uduchowioną, korzystali z zasobów wczesnej młodości i dzieciństwa. W każdym razie byli do tego predysponowani. (Ważyk 1976: 52)

Ważyk odnosił się w tym miejscu wprawdzie do futuryzmu, ale zagłębienie się w materię jako zasadnicze, przepracowywane twórczo źródło poezji awangardowej - wykraczające poza XIX-wieczną jeszcze tradycję sentymentalną, metafizyczną — przypisywał polskiej poezji eksperymentalnej tych pierwszych etapów w ogóle, nie wyłączając z tego poetyckich

6 Kornhauser wskazuje na reizm surrealistycznych ,wierszy-przedmiotów”, które, jak mówi za A.C. Danto, „nie spotykają się ze sobą w rzeczywistym, lecz jedynie w nad-rzeczywistym świecie" (Kornhauser 2018: 19). Inaczej do kwestii przedmiotowości tekstu podchodzi Agnieszka Karpowicz, która w rozdziale rozprawy poświęconej literaturze „mówionej” (m.in. Białoszewskiego, Stachury, Andermana) pisze o „rzeczowości” w tekście literackim, pomijając kwestię potencjalnej „przedmiotowości” samego tekstu (Karpowicz 2012: 364). 
konstruktywistów, w tym Peipera. Awangarda nie tyle zrywała w tej mierze z tradycją romantyzmu, ile raczej zdołała spuściznę romantyczną na nowy sposób odczytać. Zasadniczy zwrot w polskiej awangardowej liryce, umożliwiający jej rozwój i odejście futurystycznej groteski, „absurdalnych nawoływań i marzen” — stanowiło więc odrzucenie „materializmu trywialnego” i „przyjście do poezji, która jest przedstawieniem świata, zewnętrznego i wewnętrznego, wizją, nową liryką" (Ważyk 1976: 69). Zwrotu tego w książce Ważyka dokonuje oczywiście grupa „Almanachu Nowej Sztuki” 7 . To Gacki — mówił Ważyk — jako pierwszy postulował odrzucenie jednotematyczności właściwiej dla wierszy krakowskich mistrzów, Peipera i Przybosia: podnosił wartość wielotematyczności utworu, która stanowiła pochodną surrealistycznej strategii jukstapozycji i ogólnego przyzwolenia na rozprzężenie, nielogiczność, dopuszczające z jednej strony działania fantazjotwórcze, a z drugiej — zbliżanie się formuły poezji i prozy. Program Gackiego z perspektywy polskich koncepcji liryki był pełen paradoksów, w związku z powiązaniem formalnego impulsu konstruktywistycznego i dynamiki surrealistycznego przypadku:

W łonie „Nowej Sztuki” — pisał Ważyk — występowały równocześnie dwie tendencje, które można uznać za sprzeczne ze sobą i skłócone. Irracjonalizm i tęsknota do jakiegoś nowego klasycyzmu, kult niespodzianki i dążność do surowego rygoru, odwoływanie się do podświadomości i porównywanie poezji z rzemiosłem, skłonność do mistyfikacji, do żartu, do bufonady i kult dla zdobyczy naukowych, uwielbienie techniki czy maszynizmu i żądza anarchistycznej swobody, poszukiwanie treści społecznej i abstrakcyjny formalizm. (Ważyk 1966: 141)

Jakkolwiek pierwszy manifest Bretona, co zaznaczał poeta, nie przyniósł ze sobą dla poetów „Almanachu” nic interesującego, nie można już było tego powiedzieć o lekturze Freudowskiego Wstępu do psychoanalizy. Obecność psychoanalizy zdecydowała o włączaniu do wierszy materiału sennego w sposób zakładający „zniesienie hierarchii rzeczy” (Ważyk 1976: 77). Komentując własny liryk, zatytułowany Apolog, pisze poeta o tym, jak:

Kamienie, ludzie, gwiazdy, drzewa, maszyny [...] kradną sobie imiona, zamieniają się mianami. [...] Niewątpliwie pewna dążność do zrównania ludzi, zwierząt i rzeczy u futurystów przygotowała ten Apolog. [...] Była też mowa o docieraniu do struktury rzeczy za pomocą narzędzi, w których kamień, człowiek i maszyna są również zmieszane esencjonalnie. Narzędzia te nazwałem ku własnemu zdziwieniu „mitologią moich dni”. (Ważyk 1976: 77)

Ta strona, w którą, jak pisał poeta, wiersz był wysunięty, a w którą polska poezja awangardowa spod znaku Peipera nie chciała się zapuszczać, była stroną poematów prozą Artura Rimbauda - fundatorską dla francuskiego obozu surrealizmu. Lekcja szczególnego rozumienia

\footnotetext{
Do odwilżowych rozliczeń z powojenną reinterpretacją awangardy, ukazującą Peipera i Przybosia jako jej centralne postaci, odnosi się Aleksander Wójtowicz (2017: 221). Z tymi rozliczeniami autor wiąże zarówno powieść Ważyka Epizod, jak i samą Dziwną historię (por. także Cieślak-Sokołowski 2015). Zauważyć przy tej okazji należy specyfikę polskiej, przedwojennej odsłony potencjalnie surrealistycznych elementów w programie „Almanachu Nowej Sztuki”. Ani Ważyk, ani Gacki nie aprobowali wiersza, który poddany byłby tendencjom związanym z podświadomością twórczą czy pisaniem automatycznym. W tym widoczny byłby ich głęboki związek z programem poetyckim Tadeusza Peipera, a także zadłużenie w poetyckich strategiach francuskich twórców kojarzonych raczej z kubizmem. Kształt programu „Almanachu”, którego autorem był przede wszystkim Gacki, był szczegółowo dyskutowany przez wszystkich członków grupy (Wójtowicz 2017); stąd zapewne podobieństwa metapoetyckiej (choć także po prostu wspomnieniowej) refleksji Ważyka z Dziwnej historii awangardy i koncepcji Gackiego. Ważyk identyfikuje się z nimi otwarcie, upiera się przy ich ważności, ukazuje je jako wplywowe i konkurencyjne wobec programu Peipera.
} 
poezji teraźniejszości i samego materializmu - reizmu romantycznego, zakorzenionego w dziecięcej wyobraźni, w sztuce popularnej i folklorze - w metapoetyckich wypowiedziach Ważyka niewątpliwie wskazywała na jego doświadczenia z twórczością Apollinaire’a, Cendrarsa, Cocteau, Jackoba, Éluarda. Oczywiście ważne były także inne elementy zawarte w programach artystycznych Gackiego: więc konstruowanie przedstawienia w sposób odrealniony, poprzez mozaikowe zestawienia obrazów, w pewnej odległości od potocznie-realistycznych skojarzeń, opartych na zasadzie referencji znaczeń — z zachowaniem jednak sformalizowanej zasady porządkowania poetyckiej materii, wprowadzonej przez krakowskich prawodawców (chodziło zwłaszcza o najważniejszą z tej perspektywy sprawę związku pomiędzy poetyckimi zdaniami; o postrzeganie całości utworu jako konstrukcji z pięknych zdań) ${ }^{8}$. Czynnikiem konstytuującym bezhierarchiczną, choć przecież nie chaotyczną zasadę surrealistycznej składni nowej poezji ${ }^{9}$, było jednak nie tyle konstruowanie zamkniętej całości poprzez rozkwitającą formułę składniową, a właśnie jukstapozycyjne złożenia akcentujące „luźnośç” sennych skojarzeń składających się na wierszowy kolaż ze słów. Te punkty manifestów Gackiego, na których zwłaszcza mi zależy — poza mocnym podkreślaniem zarówno społecznego, jak i przedmiotowego charakteru nowej sztuki - zostały zawarte w pierwszym numerze pisma. Należy do nich twierdzenie o „immanentnym”, wykraczającym poza dualizm przedstawienia i przedstawianego, charakterze „Nowej Sztuki”, która „jest jednością” — forsuje „nieprzebyty mur dualizmu”: wyrażanych i wyrażających, naśladowanych i naśladujących, uogólnianych i uogólniających, o który rozbijają się wszystkie inne artystyczne „-izmy” (Gacki 1924: 15). Ważny jest także, akcentowany w kolejnych wypowiedziach, procesualny czy performatywny, jak dziś byśmy powiedzieli, a jak kiedyś raczej to określano: „ruchomy” charakter poezji. W tekście Na drodze do nowego klasycyzmu Gacki pisał o anektowaniu do poezji stanów marzenia sennego, odruchów automatycznych, które przynoszą radykalną zmianę techniki poetyckiej (Gacki 1925: 6); akcentował przy tym rolę technik filmowych, które w poezji miały przynieść szybkość asocjacji, skróty, wybuchowość liryczną i obrazową. Wskazywał na francuskie źródła tych twórczych strategii w polskiej nowej poezji i, podobnie jak Ważyk, wiązał te nowe tendencje z szeroko pojętym „bergsonizmem”. Pisał więc na przykład:

poezja współczesna jest stenogramem z podróży po szeregu rzeczywistych lub możliwych stacyj z tem jednak, że następstwo ich, intensywność czas trwania i t.d. [sic!] mogą nas przenieść w samo serce ruchu. Poezję francuską można nazwać poezją ruchu. Freud pogłębia tylko jej zakres działania. Bouchary znajduje dla niej inną nazwę: „romantyzm energetyczny”... nie romantyzm czysty, bo nie chodzi o nastrój, nie symbolizm, bo bez odniesienia do Absolutu, ale od strony „nowych związków uczuciowych, wyobrażeniowych, woluntarnych”. (Gacki 1925: 6)

8 Ważyk w Dziwnej historii awangardy pisał, że Nowe usta Peipera, z jego zasadniczym postulatem, aby poemat był „budową pięknych zdań”, nie powstałyby, gdyby nie polemika Peipera ze Sternem w starciu o surrealizm. Dopiero artykuły czytane w „Almanachu” miały zmusić papieża polskiej awangardy do przyznania tego, na co nie był gotowy w artykułach ze „Zwrotnicy”: „że [...] obca jego praktyce sprawa związku między zdaniami jest bardzo doniosła” (Ważyk 1976: 72).

9 Składnię rozumiem w tym miejscu szeroko, nie tylko w odniesieniu do struktury wypowiedzenia, ale także jako poetycką strategię konstruowania dużych formatów twórczych. Składnia zdania i „składnia” ciągu wypowiedzeń w wierszu (cięta poprzez elipsy bądź przeciwnie namnażająca swoje składowe poprzez addycje i tautologizacje) była zasadniczym nośnikiem eksperymentu awangardowego w polskim wydaniu. O retoryczno-składniowej kompozycji konstrukcjonistycznego wiersza awangardowego piszę w książce Performatywy. Sktadnia/ retoryka, gatunki i programy poetyckiego konstruktywizmu (2019). 
Można powiedzieć, że ta procesualność, ruchomość i swoista materialność poezji, porządkowana zgodnie z wewnętrznymi kryteriami warsztatu poetyckiego montera - zawsze osadzająca twórczość w społecznie rozumianej praktyce - powtórzona zostaje po latach aprobatywnie przez autora Labiryntu, odnajdującego w „Almanachu” początki własnego myślenia literaturą. Zwłaszcza istotne wydają się inspiracje Almanachowców technikami filmowymi, co znalazło przedłużenie w powojennych pismach Ważyka, upatrującego w nich koronne źródło najważniejszego zabiegu poetyckiego tego odłamu poetyckiej awangardy:

To, co się w technice filmowej nazywa montażem, zestawienie obrazów, zbiegało się z moją skłonnością do upatrywania głównej wartości, głównego źródła emocji poetyckiej, w jukstapozycji. Parafrazując słynny postulat Horacego o słowach, które powinny się sobie dziwić, mógłbym powiedzieć, że poezją były dla mnie zdania, które się sobie dziwią. Zdania, obrazy, zdarzenia. (Ważyk 1982: 59-60) $)^{10}$

Koncepcje poetyckie Ważyka, wywodzące się z programu „Almanachu”, żywo przywodzą na myśl ideę „obrazu-ruchu” Gillesa Deleuza, pochodzącą z książki Kino z 1983 roku, ale znajdującej swoje antecedencje zarówno w eseju Proust $i$ znaki, jak i pewne podsumowanie w napisanej wspólnie z Félixem Guattarim książce Co to jest filozofia? z roku 1991. Sposób, w jaki francuski filozof pisze o literaturze i filmie w kontekście pojęcia „obrazu-ruchu”, wywiedzionego z reinterpretacji filozoficznych wywodów Bergsona, pozwoli powiedzieć więcej o „surrealistyczności” koncepcji poetyckiej Adama Ważyka. W Amfionie czytamy:

W czasach, kiedy Amfion wznosił mityczne mury obronne, w epoce ustnego przekazu, budowa wiersza chroniła przekaz od zapomnienia i zniekształceń, powstrzymywała niszczycielskie działanie czasu. W cywilizacji druku ta funkcja mnemoniczna została bardzo uszczuplona, wiersz jednak zachował swoją trwałość w tym sensie, że bardzo silnie opiera się próbom przekodowania. Nie sposób go opowiedzieć lub zrelacjonować bez zatraty czegoś, co wydaje się najistotniejsze. [...] Ubytek informacji jest odpowiednikiem wzrastania entropii. Organizacja wiersza, powołana do opóźnienia tego procesu, sama mu również podlega. (Ważyk 1983: 46-47)

Ciekawy jest sposób, w jaki polski awangardysta widzi wiersz — nie jako nieruchomą, uwięzioną na kartce strukturę, „sytuację liryczną” rozumianą jako mimetyczna reprezentacja uprzednio rozpoznanej całości i zarazem przedstawienie lirycznej jaźni — ale jako zmieniającą się, upłynniającą, estetyczną wartość, która poprzez swoją organizację stawia opór entropii, nieustannie pogrążającej w chaosie doświadczany świat we wszystkich jego przejawach. Budowa wiersza jest więc niczym mityczne mury obronne - i w tej metaforze wydaje się tkwić coś więcej niż tylko zwykła analogia. Ważyk pisał o wierszu, pozostając zawsze blisko

10 Aleksander Wójtowicz poświęca rozdział swojej książki, Charlie w Inkipo (2017: 187-201), na omówienie wpływu, jaki miało amerykańskie kino na francuskich i polskich surrealistów, przedstawiając także bogatą bibliografię na ten temat. Ówcześni bohaterowie poetyckiej wyobraźni to m.in. Buster Keaton, Chaplin, William S. Hart. Autorskie kino Chaplina, zwłaszcza komiczna postać, jaką w jego ramach wykreował, pozostawały inspiracją tak dla Aragona i Soupaulta, jak i dla Gertrudy Stein. Chaplin traktowany był powszechnie jako „poeta”, skutecznie przekraczający granicę między sztuką a życiem. W Kwestii gustu także Ważyk pisze o Chaplinie, stawiając tezę, że kino wydało mędrca, który uprawiał filozofię nonsensu. Bohater mojego szkicu dzielił tę fascynację z Watem, Sternem, Kurkiem, którzy również pisali artykuły na temat tej gwiazdy kina niemego. Według Wójtowicza artysta kinowy stał się mimowolnym sprzymierzeńcem twórców z kręgu Nowej Sztuki. O samym surrealistycznym filmie i fotografii (oczywiście nie tylko o tym) traktuje książka Agnieszki Taborskiej Surrealizm. Spiskowcy wyobraźni (2013). 
poetyckiego materiału, odnosząc się przeważnie do rytmów, stóp, składni, spraw wersologicznych bardziej niż do choćby najfantastyczniejszych, najbardziej amorficznych, wieloośrodkowych i wielowymiarowych przedmiotów, w sensie wyglądów czy sytuacji. Wyobraźmy więc sobie wstrzymujące entropię, a zarazem rozpadające się „mury” ze składni — aby znaleźć się bliżej Ważykowej koncepcji wiersza wolnego. Ich „materialność” zostaje określona przez ich funkcję, nie w odniesieniu do pojęcia trwale istniejącej czy po prostu mogącej stanowić punkt odniesienia dla choćby ontologicznych rozważań, metafizycznie rozumianej „całości”.

Rozważania o filmie Gille’a Deleuze’a oparte są, jak wiadomo, na wykładach dotyczących Materii i pamięci (1896) oraz Ewolucji twórczej (1907) Henri Bergsona. To książka bardziej filozoficzna niż dająca powody do filmoznawczych, czy nawet kulturoznawczych rozważań teoretyków i krytyków X Muzy (choć oczywiście i takie elementy odnoszące się do klasyfikacji czy historii filmu zostają w niej zawarte). Frapujące są zwłaszcza - w kontekście poezji — rozważania dotyczące istoty obrazu-ruchu. Pokrywają się one z Deleuzjańskimi założeniami, wywodzącymi się z lektury dzieła Spinozy, wykluczającymi wszelkiego rodzaju opozycyjne uporządkowania, dotyczące fenomenów biologiczno-społecznej przestrzeni stawania się nie-ludzkiego świata. „Rzecz i percepcja to jedno i to samo” pisał Deleuze (2008: 74), oddalając eleganckim gestem modernistyczne rozważania dotyczące tego, co wyrażalne i niewyrażalne, esencjonalne i przypadkowe, znaczące i znaczone. Podstawą rozważań filozofa są twierdzenia związane $\mathrm{z}$ „nowożytnym” rozumieniem ruchu, które przynależeć ma także technikom filmowym. Bergson kontrastował go z ruchem w tradycyjnym rozumieniu, złożonym z nieruchomych odcinków, „wiecznych pozycji” — więc nieuchwytnym: „narzucamy sobie Całość, zakładając, że «wszystko jest dane», podczas gdy ruch realizuje się tak, jakby całość [...] nie mogła się udzielić” (Bergson 1957: 310, cyt. za: Deleuze 2008: 15). Autor Kina twierdzi, że w odniesieniu do nowożytnej koncepcji ruchu, właściwej już dla Materii i pamięci, u Bergsona funkcjonowało natomiast pojęcie „obrazów będących ruchem”: raczej w porządku mechanicznego następstwa nieuprzywilejowanych chwil, nie zaś dialektycznego porządku znaczących i nieznaczących pozycji, w zgodzie z zasadniczym dla tego filozofa pytaniem o trwanie i możliwość nowości. Ruch filmu wyraża trwanie: „odnosi przedmioty zamkniętego układu do otwartego trwania, trwanie zaś - do przedmiotów układu, który przez ruch jest zmuszony do otwarcia. Przedmioty, między którymi następuje ruch, odnosi do zmiennej całości, którą wyraża - i na odwrót” (Deleuze 2008: 19). Taka autoteliczna koncepcja ruchu zostaje stworzona poprzez mechaniczne następowanie po sobie odcinków ostatecznie wprawionych w ruch — powiedzieć by można, odnosząc się już do Ważyka poprzez maszynę filmu, ale też, jak warto dopowiedzieć, nowożytnej książki, nowożytnie rozumianego snu czy pamięci. Sposób działania tej „maszyny”, ruchomej i w ruch wprawionej, pozostaje samozwrotny i paradoksalny, zamknięty w zespolonych ze sobą sztucznie klatkach, obrazach, zawierających w sobie ruch immanentnie-powtarzalny na swoich własnych warunkach. Jeśli rozumieć go jako serię dowolnych nieuprzywilejowanych momentów, nieskładających się na modernistyczne/fenomenologiczne „wieczne pozycje”, powiedzieć można, że ruch ten nie tylko zostaje opisany/ukonstytuowany przez następujące po sobie obrazy, ale że także je st obrazami: „Obraz będący ruchem i materia będąca upływem są dokładnie tym samym - pisał Bergson w Materii i pamięci - Naprawdę ruchy materii są bardzo jasne 
jako obrazy, i nie ma potrzeby szukania w ruchu czegoś innego niż to, co się w nim widzi” (Bergson 1926: 7, cyt. za: Deleuze 2008: 69) ${ }^{11}$.

„Kino - pisze Deleuze - w jeszcze większym stopniu niż malarstwo, uwypukla rzeźbę czasu, perspektywę czasu - wyraża sam czas jako perspektywę lub rzeźbę" (2008: 32). Wyobraźmy sobie teraz koncepcję awangardowego wiersza, związaną z podobnie nowożytnym rozumieniem ruchu i czasu, w której wiersz to obraz będący ruchem; ruchem budowy wiersza jako doświadczenia budującego podmiotu — wewnętrznego i zewnętrznego zarazem. Także w tym przypadku będziemy mówić o „rzeźbie” lub „architekturze czasu” uwypuklonej przez wiersz — w każdym momencie trwania-czytania jednocześnie ruchomy i uprzedmiotowiony; w swoim uprzedmiotowieniu zawierający także ruch jakby następujących jedna po drugiej klatek. Stanowiłby on właśnie obrazo-ruchome wyrażenie nowożytnego czasu w szeregu dowolnych, nieuprzywilejowanych momentów trwania - będących złożonymi słowami, zbudowanymi ze słów obrazami czy też elementami długich, ciągnących się kompozycji wspominania, jak w najbardziej znanych poematach Ważyka: Labiryncie, Wagonie czy nawet Poemacie dla dorostych.

Ruch w wierszu, według Stefana Kordiana Gackiego, ucieleśniała, jak pisałam, francuska, surrealistyczna awangarda — ze względu na szybkość asocjacji, skróty, wybuchowość liryczną i obrazową - pokrywającą się z ówczesnym, surrealistycznym „bergsonizmem”. Takie rozumienie wiersza jako ruchu nie jest dalekie od rozważań Deleuze’a i Guattariego związanych już z samą literaturą, a pochodzących z książki Co to jest filozofia? Tak jak pojęcia są zdarzeniami filozofii, tak percepty i afekty (niełączące się u nich, jak wiadomo, z bardziej tradycyjnie rozumianymi percepcjami i przeżyciem — stanowiącymi poniekąd świadomościowe odbicia zjawisk) są zdarzeniami sztuki. Są w nich wytwarzane i jednocześnie się w nich „samoustanawiają”, skoro "myślenie i byt są tą samą rzeczą” (Deleuze i Guattari 2000: 46). Sztuka utrwala - ale jest także jedyną rzeczą na świecie, która utrwala siebie: „dzięki samoustanowieniu tego, co stworzone”: „To, co się utrwala, rzecz lub dzieło sztuki, jest blokiem wrażeń, to znaczy połączeniem perceptów i afektów” (Deleuze i Guattari 2000: 46). W ten właśnie sposób rzecz staje się niezależna od swego modelu, od innych ewentualnych postaci, które same są rzeczami-artystami, postaciami malarskimi — lub, jak dodalibyśmy — pisarskimi, oddychającymi powietrzem malarstwa - czy też pisarstwa - w sposób autonomiczny zarówno wobec aktualnego i przyszłego widza, jak i od swego twórcy.

Prace eseistyczne Ważyka, przedstawiające historię awangardy (jak Dziwna historia) czy będące prywatnym dziennikiem lektury (Kwestia gustu), a w końcu wypowiedzi na temat cudowności i (specyficznie rozumianego) realizmu w polskiej literaturze romantycznej (Cudowny kantorek) są pełne odniesień do materialnych przedmiotów i zmysłowych postrzeżeń. Dla samego poety wydają się one uobecniać nie tyle jako przedstawienia ponadczasowych,

11 Obraz-ruch — to nie tylko postrzeżenia i przedmioty, ale także sam postrzegający; dopiero te wszystkie elementy stanowią razem obrazy ruchu. Deleuze dodaje:

Atom jest obrazem, który sięga tam, skąd biorą się jego akcje i reakcje. Moje oko, mój mózg to obrazy, części mojego ciała. W jaki sposób mój mózg miałby zawierać obrazy, skoro sam jest obrazem wśród obrazów ? Zewnętrzne obrazy działają na mnie, przekazują ruch mnie, a ja odwzajemniam ruch — jakim sposobem obrazy mogłyby znajdować się w mojej świadomości, skoro ja sam jestem obrazem, to znaczy ruchem? [...] Ja, moje ciało byłoby raczej zbiorem nieustannie odnawiających się molekuł i atomów. [...] Nie odróżniają się one od światów, od wzajemnych wpływów atomów. To zbyt gorący stan materii, by można było w nim wyodrębnić ciała stałe. To świat nieustannej zmiany, powszechnego falowania, chlupotania — nie ma ani osi, ani środka, ani prawej strony, ani lewej, ani wysoko, ani nisko. (Deleuze 2008: 69) 
wiecznych, uprzywilejowanych momentów w poezji. To zwykle raczej „przedmioty” sytuacyjne, charakteryzowane przez pełnione przez nie funkcje, które można by określić właśnie jako obrazy w ruchu, czy — żeby pozostać wiernym filozoficznej koncepcji Deleuze'a — jako obrazy-ruchy: oznaczające zawsze interwały trwania, podróży, nie zaś pojedyncze, domknięte, podmiotowo dookreślone doświadczenia. To przedmioty, na których dotykalności Ważykowi zależy, ale którą znamionuje, „dotykając” ich poprzez wykreowane obrazy. Kojarzą się one zawsze w relacjach, które można by uznać za konstelacyjne: jeśli nie wprost kolażowe, to zawsze dążące do jukstapozycji jako zasadniczego, królewskiego zabiegu „strukturowania” poetyckich tekstów Ważyka. Poeta powoływał się również na charakter nowoczesnej wiedzy, która prowadzić miała do ujmowania rzeczywistości jako zbioru zdarzeń, zarówno z punktu widzenia probabilistyki — jak i codziennego doświadczenia. Kiedy Ważyk systematyzuje (między innymi) własne działania twórcze i określa ich związek z owymi doświadczeniami — opisuje je w kategoriach przywodzących na myśl Deleuzjańskie refleksje nad sztuką:

Od urodzenia do śmierci żyjemy w świecie zdarzeń rozmaitej dla nas doniosłości. Zaobserwowane zdarzenia przynoszą nam jakieś informacje, które przerabiamy na system naszych znaków, chcąc je przekazać komu innemu. Wybieramy zdarzenia, szeregujemy, ustalamy związki przyczynowe. Zbiór, z którego zostały wybrane, może się pokrywać z przestrzenią doświadczenia życiowego i historycznego, albo obejmować również przestrzenie mitów, baśni, snów i hipotetycznych stanów infra-sennych. Zdania, słowa, fonemy, litery są również zdarzeniami. Otrzymują podobną, ale bardziej przejrzystą organizację. (Ważyk 1966: 7)

Ważyk - w zgodzie z programem Gackiego — nie oddziela zdarzeń i słów, zewnętrznych przeżyć i wytworów własnego intelektu, a także i tego, co wiąże się z życiem pojętym psychicznie i tym, co zależy od twórczej systematyzacji, konkretyzującej obrazy w interwały, w ruchome konstrukcje. W ten sposób przede wszystkim najważniejszy, powojenny przedstawiciel grupy „Almanachu Nowej Sztuki” pozostaje powojennym polskim surrealistą. „Filmy” takich wierszy Ważyka, jak Labirynt czy Wagon, to nie po prostu poematy pamięci, które mogłyby się toczyć w nieskończoność; to wiersze, które w nieskończoność się toczą, jeżeli "powrócimy do tej czy innej strony, do tego czy innego momentu” ${ }^{12}$. Określenie filmu - czy też wiersza - jako „rzeźby”, uwypuklającej czas w perspektywie, świetnie pasuje do poetyckiej koncepcji Ważyka: jukstapozycyjnej, pozbawionej hierarchii, parataktycznej i ukazującej upływ czasu, pracę entropii na opierających się degradacji doświadczenia w pamięci konstrukcjach, także wersyfikacyjno-składniowych.

Warto przy tym wziąć jeszcze pod uwagę słowa Deleuze'a/Guattariego dotyczące sposobu, w jaki sztuka poprzez percepty i afekty rekomponuje serie rozmaitego rodzaju zdarzeń: „Sztuka ujmuje kawałek chaosu w ramę, aby stworzyć chaos skomponowany, który staje się odczuwalny lub z którego czerpie ona wrażenie chaoidalne jako różnorodność” (Deleuze/ Guattari 2000: 227). Teza ta staje zaskakująco blisko rozmaitych awangardowych i neoawangardowych ujęć sztuki, które - nawet kiedy są konstruktywistyczne - nie roszczą sobie

12 Lekturą Wagonu Adama Ważyka kończy swoją Poetykę doświadczenia Ryszard Nycz (2012). W jego interpretacji wartość poematu polega na artykulacji trzech rodzajów doświadczenia: doświadczenia XX wieku, doświadczenia autobiograficznego i doświadczenia metapoetyckiego, a w punkcie dojścia ukazuje niemożność ich narracyjnego uporządkowania, a więc zrozumienia. 
pretensji do porządkowania Całości. Nawet takie koncepcje sztuki, jak te związane z surrealizmem, szukające swoich uzasadnień w perspektywie głębokiej psychologii, snu, obłędu, rzeczywistości alternatywnych i automatycznego pisania, niosą w sobie impuls konstrukcyjny (Kornhauser 2015: 45-55). Idąc za Deleuzem, należałoby powiedzieć, że nie ma nic bardziej „jukstapozycyjnego” z zasady niż właśnie idea „obrazu-ruchu” wytworzona na potrzebę ujęcia ruchu filmowego; to bowiem ruch zmiany, który zawiera w sobie zestawienia jako swoją główną zasadę i jako swoistą własność zmieniających się ujęć. Zainteresowanie poetów awangardowych technikami filmowymi to sprawa oczywista; wydaje się jednak, że bardzo wielu strategii eksperymentalnych awangardy, jeżeli chodzi o konstruowanie krótkich i komponowanie długich fragmentów tekstu, po prostu by nie było, gdyby nie świadomość tych technik. Mnemotechniczno-ruchoma koncepcja aktu poetyckiego Ważyka mieści się w podobnym mechanizmie. Jeżeli mielibyśmy przywołać za Deleuzjańską lekturą Spinozy reguły towarzyszące spostrzeżeniu kompozycyjnej zasady funkcjonowania bytów, ciał czy też myśli i dzieł sztuki na płaszczyźnie immanencji, będącej także płaszczyzną artystycznej praktyki, to moglibyśmy zwrócić uwagę na fakt, że podobnie jak określenia charakteryzujące dzieła sztuki (percepty i afekty) są one dwojakie: zostają uporządkowane poprzez siatkę współrzędnych - długości, czyli „zbioru stosunków przyspieszenia i spowolnienia” i szerokości, czyli „zbioru afektów, [...] stanów intensywnych pewnej nieokreślonej sity (siły istnienia, bycia pobudzanym)” (Deleuze 2003: 205-206; podkr. autora). Na tej samej zasadzie przeinterpretować można jako „ruchową” kompozycję poematów Ważyka. Zbiór stosunków napędzających i spowalniających zachodzenie narracji pamięci (za Ważykiem moglibyśmy powiedzieć: poprzez formę wstrzymujących entropię zjawisk) dałoby się ująć więc zarówno w kategoriach rozmaitych form i strategii gatunkowych jego poezji, jak i samych konstrukcji składniowych wiersza i w końcu retorycznych figur kompozycyjnych, figur myśli. Niekoniecznie definiują one w punkcie dojścia obraz pamięci jako możliwą do objęcia, quasi-mimetyczną Całość. Przeciwnie, ukazują „składniową” rzeźbę pamięci, mijającego czasu: pewną perspektywę, którą można sobie wyobrazić jako ruchomą rzeźbę poprzez palimpsestowe nałożenie wszystkich tworzących ją klatek albo rozpiąć w perspektywę jak złożony z szeregu migawek czas w filmie (Deleuze 2008: 32). Tak na przykład w Wagonie „ruchowa” konstrukcja poetycka staje się widoczna przez składniowo-kompozycyjne spowolnienia, dotykalna dzięki zabiegom tautologizacji, repetycji, różnego rodzaju nawrotów i przestawni ruchomych, jukstapozycyjnie złożonych, a równorzędnych w swoim znaczeniu i zmieniających się z klatki na klatkę figur poematu. Napędzana zaś jest afektywnie poprzez pewną zasadniczą dla Ważyka namiętność patrzenia i przypominania sobie, porównywania przeszłości i teraźniejszości w zgodzie z mocnym impulsem „odpodobnieniowym”: nieustannego re-produkowania surrealizującej percepty różnicy, która okazuje się samą esencją upływającego czasu i głównym mechanizmem wyobraźniowo-rzeczowych repetycji. Wagon to tylko jeden z wielu wierszy czy poematów, które można by w tym miejscu przywołać, bowiem surrealistyczna metoda komponowania rucho-obrazów jest czymś charakterystycznym dla poetyckiego sposobu myślenia autora w całej właściwie rozciągłości jego dzieła (zastanowić by się może należało tylko nad wierszami okresu socrealistycznego, z wyłączeniem jednak wielu z nich). Wiersz Próba, pochodzący z podobnego okresu, może posłużyć za poetycką definicję zasady rządzącej wspominanym poematem: 


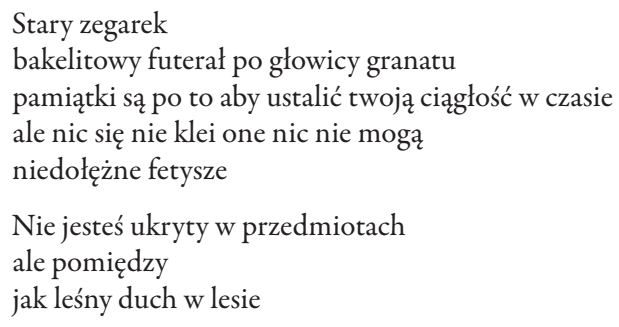

(Ważyk 1978: 156).

Marta Koronkiewicz, pisząc o przechadzkowym charakterze codziennościowej poetyki Ważyka, w pewnym momencie, za Michelem de Certeau, odwołuje się do asyndetonu jako jednej z najważniejszych w tym przypadku figur składniowo-retorycznych (Koronkiewicz 2018: 66). Bezspójnikowe łączenie wypowiedzeń odpowiada nie tylko domyślnym krokom podążającego przez miasto bohatera, ale stanowi podstawę do łączenia obrazów - tych przepływających przez głowę spieszącego przechodnia, jak i mijanych przez niego miejsc i widoków. Asyndeton byłby także zasadniczą formą retoryczną filmowego perceptu-pamięci. W Wagonie z tego punktu widzenia mielibyśmy do czynienia z serią obrazów: tego, co odbywa się w samym przedziale, „ludzi za szybą idących w głąb korytarza” (Ważyk 1978), widoków za oknem - i także wizji przeszłości powstających w umyśle marzącego bohatera pod wpływem wypowiadanych przez podróżnych słów. Niektóre z tych obrazów są obrazami „nawracającymi” (jak ciągle przechodzące korytarzem wagonu kobiety — nowocześnie umalowane lub wręcz przeciwnie, zgrzybiałe, prowadzące dzieci, szczupłe, przysadziste, chłopki i młode dziewczyny — koresponduje z nimi jeszcze list od żony i wspomnienie o własnych dzieciach). Niektóre składają się z nowych uwag i percepcji, kiedy wagon zarzuca, staje na stacji, kiedy przychodzi konduktor czy wsiadają nowi pasażerowie. Następują one wobec siebie właśnie w porządku „bez-spójnikowym” — nic właściwie nie motywuje zmian obrazów poza ruchem obserwowanych przez podmiot „nieuprzywilejowanych” w żaden sposób zjawisk i poza upływającym czasem. Podobnie jak w trakcie jazdy pociągiem doświadczenie ruchu jest paradoksalne: czas wydaje się płynąć inaczej wewnątrz pociągu i na zewnątrz, jeszcze inaczej zaś - bo zazwyczaj wstecz — płynie w myślach poetyckiego narratora, stanowiącego jeden z elementów całości przedstawienia. Jednocześnie w sposób typowy dla Ważyka owe przepływy regulowane są i utrwalane także na niższym poziomie organizacji kompozycji, poprzez właściwą dla tego poety organizację składniową wiersza wolnego w swoistej tej formy reinterpretacji. Wystarczy przeczytać choćby kawałek:

Patrzysz na ludzi za szybą idących w głąb korytarza,

Jest tam manekin z baczkami w rurkach wąziutkich spodni

Dziewczyna z twarzą ujętą w płomyki czarnej pochodni

obnaża jedno ramię starannie według mody

Taki widok rozczulał cię i drażnił kiedy byłeś młody

(Ważyk 1978: 148),

żeby zobaczyć, jak głęboka była tendencja Ważykowego werlibryzmu do regularności. 
Podobnie jak w wielu innych wierszach i poematach, Ważyk odwołuje się w tym miejscu w sensie wersyfikacyjnym do dystychu kubistycznych poematów Apollinaire'a i Cendrarsa w polskiej wersji, znanej z jego własnych tłumaczeń ${ }^{13}$. Wiersz wolny Ważyka nie tyle zależał od prozodii czy od arbitralnej decyzji autora, jeśli chodzi o impuls wyznaczający klauzulę wersu — jak jest to przyjęte w tradycji polskiej, XX-wiecznej wersyfikacji — ile raczej chodziło o swego rodzaju napięcie pomiędzy dwiema tendencjami wersyfikacyjnymi: tradycyjnymi formatami wiersza regularnego polskiej poezji i sposobem, w jaki są one rozbijane, nadwerężane poniekąd pod wpływem ciśnienia wpuszczanego do poetyckich fraz wraz z językiem mówionym, rytmizowanym więc w zgodzie z prozodią zwykłego wypowiedzenia ${ }^{14}$. W ten sposób w wierszu wolnym Ważyka zawsze idą o lepsze dwie formuły delimitacyjne wiersza: ta związana z jego regularnością, wyznaczana przez liczbę sylab, honorująca niezwykle ważną u autora Wagonu średniówkę z rozpraszającą, rozbijającą tę regularność tendencją do akcentowania raczej granic składni i wypowiedzenia w wierszu, z wybijającą się w nim prozodyjną determinantą kadencji i antykadencji. Widać to także w zacytowanym przeze mnie fragmencie, w którym w wersie „obnaża jedno ramię starannie według mody” ujawnia się tradycyjny format regularnego sylabotoniku 14-zgłoskowego, z mocną średniówką po 7 sylabie, zapisany jeszcze w tym miejscu „pociągowym” jambem. Ten właśnie format — niczym mury obronne Amfiona — jest rozbijany, rozpychany, rozpraszany przez język niemieszczącej się w nim obrazowej pamięci. Wydłuża się więc i skraca linijka — od 15, 16, aż w końcu do 17 wersów w kodzie strofy, dodatkowo skomplikowanej możliwością wyznaczenia w niej aż dwóch średniówek. W większości wersów - co typowe dla dystychu Apollinaire'owskiego (w postaci wypracowanej w Ważykowym tłumaczeniu Strefy) — zasadniczy format to równa liczba sylab w pierwszym hemistychu i nieregularna w drugim. W przypadku naszego cytatu to $(8+x)$, za wyjątkiem wspomnianego wtrętu 14 zgłoskowego. Przedział po-średniówkowy ulega każdorazowo swoistemu zepsuciu i przez wytracenie regularności widocznej w częściach nagłosowych, flirtujących z heksametrowym daktylem, i przez nierówną za każdym razem w wygłosie liczbę sylab. Rymy wiążące wersy są przy tym raczej dokładne, także w całości poematu, co rzadkie u Ważyka przy stosowaniu tego dystychu, zazwyczaj komponowanego w całość poprzez asonanse. Ciekawy jest zwłaszcza sposób, w jaki regularność zostaje wytracona w ostatniej linijce tej strofy: „i drażnił” — w zgodzie z polisyndetonową składnią zbierającą orzeczenia w związek „rozczulał cię i drażnił” - może zostać włączone do działu przed-średniówkowego albo - w zgodzie z narzuconą przez całość strofy tendencją rytmiczną - stać się elementem po-średniówkowego wygłosu, z mocno osłabioną średniówką

13 O Apolinnaire'owskim dystychu jako jednym z ulubionych formatów wiersza wolnego Ważyka pisałam w tekście: Dziwna historia Adama Ważyka (Orska 2012).

14 W Eseju o wierszu Ważyk pisał, że wiersz wolny w Polsce występował przeciw skonwencjonalizowanej składni wiersza regularnego. Rym, stosowany w takim wierszu - przede wszystkim asonans - również stanowił środek przeciwko młodopolskiej rozlewności: „Długi dystych rymowany trafił na szczególnie podatny grunt. Używali go prawie wszyscy poeci w kręgach nowatorskich" (Ważyk 1964: 120). Wiersz ten zachowywał średniówkę, ale bardzo ruchliwą. Ważyk określał ten wiersz jako „zdeformowany trzynastozgłoskowiec”, zaznaczając „,swobodny jego rzut na inną płaszczyznę, na płaszczyznę, gdzie przełamane zostały tradycyjne podziały na lirykę, opis i refleksję" (Ważyk 1964: 120). Wszystkie reguły werlibryzmu były więc ruchome: pojawiały się i zanikały rymy, podziały wersowe, zgodności toniczne, łamana była izochronia. Częste były wiersze „drobione składniowo" i antykadencyjne (tak pisali futuryści, Przyboś, Czechowicz). Wiersz wolny różnił się według Ważyka od wiersza sylabicznego, zdaniowego właśnie tym wzmożeniem antykadencyjności: „W [tym] wypadku organizacja wiersza wyodrębnia zdanie ponad potrzeby codziennego porozumienia [...] [ta] postać odpowiada szerokiej tradycji — ludowej, średniowiecznej, biblijnej, tradycji zaklęć magicznych" (Ważyk 1964: 122). 
rozcinającą ten związek. Tak czy owak, będziemy mieć wrażenie, że dysponujące własnym akcentem „i drażnił” stanowi wtrącenie zakłócające miarowy rytm wersu. Wiersz się wykoleja zresztą na wiele rozmaitych sposobów; szukając regularnych stóp, oczekujemy jakoś pobrzmiewających tu i ówdzie jambów. Wagon to rozsterowany na różne sposoby mechanizm, który zestawia ze sobą właściwie jakoś podobne, choć tak różniące się klatki rozmaitych obrazów. Jak widać, tekst rozsnuty zostaje jednak na nader mocnym wersyfikacyjno-składniowym warsztacie - zwłaszcza precyzyjnie zaś zostają dopracowane miejsca, w których ów gorset się rozluźnia, rozchodzi, niszczeje, tak jak zaszywane są puste miejsca w pogrążającej się w entropii pamięci. To właśnie zepsute zszycia odpowiadają za replikację zestawienia; konstytuują filmowy automatyzm powracania-powtarzania obrazów, które dziwią się sobie — z którymi związana jest surrealistyczna technika jukstapozycji. Jak pisał poeta:: „Ubytek informacji jest odpowiednikiem wzrastania entropii. Organizacja wiersza, powołana do opóźnienia tego procesu, sama mu również podlega” (Ważyk 1964: 24).

W Eseju o wierszu Ważyk wygłasza tezę, która wydaje się stać w sprzeczności nie tylko z programem konstruktywistycznej awangardy, ale także z jego własnymi, wersologicznymi, niezwykle precyzyjnymi dociekaniami:

poezja nie jest sztuką wiersza - pisze - [o]d czasu Whitmana w Ameryce, od Laforgue'a we Francji, od Dwudziestolecia u nas [...] poeci coraz częściej uciekali do wiersza wolnego, niekiedy programowo. (Ważyk 1964: 5)

Podaje także bezpośredni powód tej ucieczki:

Wydaje mi się [...], że wiersz zaczyna budzić nowe zainteresowania w szerszej perspektywie wybiegającej ku innym dziedzinom życia czy działalności, że staje się czymś intrygującym jako organizacja sterowana przez człowieka. (Ważyk 1964: 6)

$\mathrm{Na}$ zakończenie mogłabym postawić tezę, że ta strona, w którą zmierza wiersz (neo)awangardowy, zależy od mechanizmów innych niż te tradycyjnie powiązane z kompozycjami właściwymi dla literatury. Wskazałabym przy tym na zasadnicze znaczenie technik przedstawiania właściwych dla filmu. To one między innymi stanowią zasadnicze środki artystycznego eksperymentu w wierszach poetów, którzy obecnie jakoś podążają za surrealistyczną właśnie tradycją. 


\section{Bibliografia}

Bergson Henri (1926), Materia i pamięć, tłum. W. Filewicz, Kasa im. Mianowskiego, Warszawa. - (1957), Ewolucja twórcza, tłum. F. Znaniecki, Książka i Wiedza, Warszawa.

Brzozowski Tomasz (1994), Orientacja wizualno-plastyczna w twórczości poetyckiej Adama Wa$\dot{z} y k a$, Wydawnictwo Naukowe Uniwersytetu Szczecińskiego, Szczecin.

Cieślak-Sokołowski Tomasz (2015), „Kres obiektywny”. O trzech likwidacjach awangardy [w:] Awangarda i krytyka. Kraje Europy środkowej i wschodniej, red. Kornhauser J., Kmiecik M., Szumna M., Wydawnictwo UJ, Kraków.

Deleuze Gilles (2003), Spinoza. Filozofia praktyczna, tłum. J. Brzeziński, Wydawnictwo Naukowe PWN, Warszawa.

- (2008), Kino. 1. Obraz-ruch. 2. Obraz-czas, tłum. J. Margański, słowo/obraz terytoria, Gdańsk.

Deleuze Gilles, Guattari Félix (2000), Co to jest filozofia?, tłum. P. Pieniążek, słowo/obraz terytoria, Gdańsk.

Gacki Stefan Kordian (1924), Sztuka ludzka, „Almanach Nowej Sztuki” nr 1.

- (1925), Na drodze do nowego klasycyzmu, „Almanach Nowej Sztuki” nr 1.

Janicka Krystyna (1985), Światopoglad surrealizmu, Wydawnictwa Artystyczne i Filmowe, Warszawa.

Karpowicz Agnieszka (2012), Materialność i literatura [w:] tejże, Proza życia. Mowa, pismo, literatura, Wydawnictwa UW, Warszawa.

Kluba Agnieszka (2004), Poezja mitu kratylejskiego Adama Ważyka [w:] tejże, Autoteliczność referencyjność - niewyrażalność. O nowoczesnej poezji polskiej (1918-1939), Wydawnictwo UWr, Wrocław.

Kornhauser Jakub (2015), Catkowita rewolucja. Status przedmiotów w poezji surrealistycznej, Wydawnictwo UJ, Kraków.

Koronkiewicz Marta (2018), Flâneur? Po polsku: przechodzień [w:] Nauka chodzenia. Teksty programowe późnej awangardy, t. 1, red. Browarny W., Mackiewicz P., Orska J., Wydawnictwo UJ, Kraków.

Krzysztoszek Wiesław (1985), Mit niespójności. Twórczość Adama Ważyka w okresie międzywojennym, PWN, Warszawa-Poznań-Toruń.

Namowicz Tadeusz (2000), Wstęp [w:] Pisma teoretyczne niemieckich romantyków, oprac. i red. Namowicz T., Ossolineum, Wrocław.

Nauka chodzenia. Teksty programowe późnej awangardy, t. 1 (2018), red. Browarny W., Mackiewicz P., Orska J., Wydawnictwo UJ, Kraków.

Nauka chodzenia. Teksty programowe późnej awangardy, t. 2 (2019), red. Browarny W., Mackiewicz P., Orska J., Wydawnictwo UJ, Kraków.

Nycz Ryszard (2012), Literatura: litery lektura. O tekście, interpretacji, doświadczeniu rozumienia i doświadczeniu czytania. Z dodaniem studium przypadku „Wagonu” Adama Ważyka [w:] tegoż, Poetyka doświadczenia. Teoria - nowoczesność - literatura, IBL PAN, Warszawa.

Orska Joanna (2012), Republika poetów. Poetyckość i polityczność w krytycznej praktyce, Wydawnictwo emg, Kraków.

- (2019), Performatywy. Sktadnia/retoryka, gatunki i programy poetyckiego konstruktywizmu, Wydawnictwo UJ, Kraków.

Rimbaud Artur (1993), Listy jasnowidza [w:] tegoż, Wiersze, Sezon w piekle, Iluminacje, Listy, wyb., oprac. i posłowie A. Międzyrzecki, Wydawnictwo Literackie, Kraków. 
Surrealizm - antologia (1976), wyb., tłum. i wstęp A. Ważyk, Czytelnik, Warszawa. Ważyk Adam (1964), Esej o wierszu, Czytelnik, Warszawa.

- (1966), Kwestia gustu, PIW, Warszawa.

- (1976), Dziwna historia awangardy, Czytelnik, Warszawa.

- (1978), Wiersze wybrane, Czytelnik, Warszawa.

- (1979), Cudowny kantorek, PIW, Warszawa.

- (1983), Amfion. Rozważania nad wierszem polskim, Czytelnik, Warszawa.

- (2011), Wiersze i dwa poematy, wyb. i posł. A. Sosnowski, Biuro Literackie, Wrocław.

Wójtowicz Aleksander (2017), Nowa sztuka. Początki (i końce), Wydawnictwo UJ, Kraków. 